\title{
The Implementation of Higher Order Thinking Skill (HOTS) in Junior High School: Teaching Practice and Problems
}

\author{
Rani Ayu Feronica \\ Institut Agama Islam Negeri (IAIN) Curup \\ feronicagrande@gmail.com \\ Eka Apriani \\ Institut Agama Islam Negeri (IAIN) Curup \\ eka.apriani@iaincurup.ac.id \\ Sarwo Edy \\ Institut Agama Islam Negeri (IAIN) Curup \\ edysarwo@iaincurup.ac.id
}

\begin{abstract}
The purpose of this research is to learn about teaching practices and issues that arise when using HOTS. This is a descriptive qualitative study. This study focused on four English teachers at SMPN 1 Rejang Lebong. The data for this study was gathered using a questionnaire and an interview. Qualitative analysis was used to analyze the data. The findings of this study are as follows: (1) the application of HOTS in SMPN 1 Rejang Lebong is properly done per the Anderson Taxonomy: memorizing, comprehending, applying, analyzing, assessing, and producing Second, there were instructional issues in HOTS implementation, including (2) a lack of facilities, a lack of time, a lack of training, a lack of knowledge, a lack of connection, and a lack of desire. This discovery is intended to be utilized to understand more about the teaching and learning process in junior high school by applying HOTS.
\end{abstract}

Keywords: HOTS, Junior High School, Teaching Practice, Teaching Problems 


\section{INTRODUCTION}

Teaching English to pupils who do not speak English as their first language. Anyone interested in learning strategies for teaching English should be familiar with the field's core terminology. Teaching English as a Foreign Language (TEFL) is often done in the student's home country, either via the public school system or through private schools. Apriani (2021) observed that Maintaining communication between the teacher and students, as well as among students, when teaching English as a second or foreign language in the classroom involves the use of nonlinguistic resources in addition to linguistic ones. English as a Foreign Language (TEFL) teachers might be native or non-native English speakers (Rohmah, n.d.). We've also heard the words "language skills" and "language components" when it comes to language teaching. Listening, speaking, reading, and writing is all examples of language abilities. Receptive skills include listening and reading, whereas productive skills include speaking and writing.

In Indonesia, the English syllabus is being developed to explore the influence of English as a foreign language on the advancement of English education, communicative learning, and communicative approach in English language teaching. Because of English's international standing, this is the case. As a consequence, communicating with people from all over the world is one of the most important goals of studying English in Indonesia. According to some teachers, the role of the teacher in the teaching and learning process is to develop a communicative method through group work, discussion, or role-play. Apriani, et. al (2019)said that good communication entails not just communication inside society, but also communication on a worldwide scale. This is done to help students communicate better.

In general, teaching English is not easy. The teaching method used by the teacher determines the success of the student in the English learning process (Apriani, 2017) There are many difficulties in teaching English, especially in junior high school. In junior high school, the students must have learned a lot about English because before they had learned English how the procedures use English. It can be comprehended because English is a skill that involves many aspects of the language. The aspect is medians, vocabulary, fluency precision, expression, and style.

Based on the provisions of the Indonesian government officially changed the Education Unit Level Curriculum (KTSP) to the K 13 curriculum (KURTILAS) which has now been implemented. The purpose of this curriculum change aims to improve the characteristics of students 
Rani Ayu Feronica, et.al: The Implementation of Higher Order Thinking Skill (HOTS) in Junior High School: Teaching Practice and Problems- 187

(Students) who are seen as the increasing number of global influences that arise so that it will likely affect the character of students. in which there is a high order thinking skill (HOTS) method or critical thinking.

The 2013 Curriculum was designed to enable students to be more capable of making assumptions, asking questions, reasoning, and communicating. In implementing the 2013 Curriculum, the teachers are encouraged to implement HOTS (Higher Order Thinking Skill) learning and to assess the learning outcome in HOTS aspects of knowledge. Higher-Order Thinking Skills (HOTS) are defined as the ability to think widely to find a new challenge.

HOTS is essential for assisting with the teaching and learning processes. It is quite beneficial for pupils to encounter problems that are unusual in their daily lives. Furthermore, students with HOTS can make students recognize themselves by improving their performance and reducing their weaknesses. Curriculum 2013 (K-13) is being adopted to promote Higher Order Thinking Skills (HOTS). The assessment includes HOTS. The purpose of assessing learning outcomes is to assist students in developing their Higher Order Thinking Skills (HOTS). As a result, K-13 places a premium on students who exhibit Higher-Order Reasoning Skills. As a result, educators must be able to provide a long-term evaluation that includes Higher Order Thinking Skills (HOTS) (Pratiwi, Dewi, \& Paramartha, 2019).

High Order Thinking Skill (HOTS) an important in learning English, Also HOTS is a basic when a student wants to make a creative idea. These student-centered learning strategy is thinking skills that are more than just remembering and understanding, but also the ability to combine what is already remembered and understood to analyze, evaluate and even create. This approach sought to incorporate higher-order thought in education by analyzing and measuring instructional behavior through the emotional, affective, and psychomotor abilities of students (Fairiziana, Rosli, \& Maarof, 2017).

The number of junior high schools in Rejang Lebong has implemented the six HOTS levels completely. One of them is SMP number one. At SMPN 1 Rejang Lebong Has implemented HOTS since K13 was rolled out. Based on the results of classroom observations, the researcher found that learning English at Rejang Lebong 1 State Junior High School was very active. At SMPN 1, after the implementation of HOTS the student exam results have increased, this is evidenced by the results of the highest 2016/2017 national exam (UN) in Bengkulu Province, the first was achieved by SMPN 1 Rejang Lebong on behalf of Hanifah Harlasi with a total score of 385, secondly Nurhidayah Anggraini with a total score of 
383, the three Fanaya Armansya with a total score of 381. In the 2017/2018 academic year, the total UN score in Bengkulu Province experienced a decrease in SMPN 1 Rejang Lebong down to the second place with a total score of 284.49, but this school has the highest English score, namely 70.35 .

In the 2018/2019 academic year, the second-highest national examination score in Bengkulu province was achieved by SMPN 1 Rejang Lebong on behalf of A.M. Bagas Arianloka and Vikram Ahmad Fauzan with a total value of 39.35. Is also SMPN 1 Rejang Lebong achieved the highest average score in Bengkulu Province with a total score of 36.29 which was very satisfactory. The researcher also interviewed one of the teachers, according the teacher, it is likely that HOTS is the source of children's success in solving the questions on the national exam (UN). According to one student interviewed by the researcher, the technique used by the teacher could be followed by them well, not boring, quickly understanding.

Based on the explanation above the researcher would like to conduct this research which aimed to find out the teacher's strategy of HOTS in teaching English at Junior high school number 1 Rejang Lebong. As a result, the title of this research is "The Implementation of HOTS in Junior High School: Teaching Practice and Problems.

\section{THEORETICAL FRAMEWORK}

\section{Teaching English As A Foreign Language}

Teaching English as a foreign language can take place in any region, regardless of whether English is spoken there. Exam planning, career development, furthering one's education, and other factors motivate EFL students to learn English. Most countries' curricula include English as a foreign language, especially in public schools. Indonesian senior and junior high schools require English as a subject. At the lower levels, such as primary schools and kindergarten, English is not a mandatory subject, but it can be taught as a local material subject to students (Supriyanti, Triastuti, \& Bahasa, 2008).

There are five tiers of teachers in the TEFL field (Susilo, Suhatmady, Sunggingwati, Farisa, \& Ilmi, 2017): ((1) the opportunist who has no EFL or other teaching credentials but wants to find work; (2) the teacher who has completed a basic level of training of 20 hours or less; (3) the TEFL initiated teacher who has completed a certificate level TEFL course of approximately 100 hours; and (4) the teacher who has been trained in another subject but needs to learn the concepts of teaching EFL. 
People at this stage have studied English extensively, most likely receiving a bachelor's or master's degree in English literature or linguistics, but have no teaching experience; (5) The TEFL trained instructor with a diploma or master's-level certification in EFL.

\section{Teaching English For Junior High School}

English is taught as a compulsory language in junior and senior high schools. Of course, the national industry has already begun to introduce English at lower levels, such as primary school and kindergarten. English training starts in junior high schools at the age of eleven, in the first grade, and continues to university levels. Despite spending nearly seven years in school studying English, students are unable to communicate in English in real-life circumstances (Akbari, 2015).

In general, and particularly in our nation, teaching English as a foreign language is a difficult task in developing countries. First and foremost, English language proficiency requires access to and use of the most up-to-date technology and science tools in English. Second, learning English is needed to meet the demands of the information age and to make effective use of the Internet. Third, mastery of the English language promotes cross-national cultural exchange, including the idea of civilizational dialogue.

\section{The Implementation of High Order Thinking Skill (HOTS)}

The learning process should start with something simple and move to something more difficult. That is, competency evaluation begins with a multitude of HOTS. Data from the International Student Assessment Program (PISA) suggest that higher-order thinking is poor in Indonesia. Furthermore, Indonesia is ranked 69th out of 76 countries (Kemendikbud, 2007).

To educate pupils for the twenty-first century, the Ministry of Education and Culture created the 2013 curriculum (K-13). The 2013 Curriculum (K-13) emphasizes Higher Order Thinking Skills (HOTS). HOTS learning activities are created in the classroom by teachers.

The Ministry of Education defines Higher Order Thinking Skills (HOTS) are defined as the capacity to solve issues, make judgments, be inventive, and generate something using logic and reflection (Febriani, 2019). Higher-order thought is described as thinking that takes place at the top of the cognitive processing hierarchy. 
The most widely known hierarchical arrangement of this kind of education is Bloom's Taxonomy, which views a spectrum of thought skills starting with knowledge-level thinking and ending with evaluation-level thinking. Imaginative and critical thought, analysis, problem-solving, and visualization are all examples of higher-order thinking skills (HOTS) (Jennifer Lyn S Ramos, Bretel B Dolipas, and Brenda B Villamor,2013).

Dr. Benyamin Bloom, an educational psychologist Bloom's Taxonomy was created in 1956 by Edward Bloom, who was born in Pennsylvania and received his Ph.D. in education from the University of Chicago in 1942. Taxonomy and classification are synonyms. Taxonomy, according to Pratiwi, is a categorization structure based on shared concepts or norms. Bloom Taxonomy is a categorization framework he created for cognitive thinking abilities. It has had a significant impact on schooling during the last 50 years (C-Leslie, 2016). The Bloom taxonomy was created in the 1970s as a tool for objective-based evaluation and as a paradigm for generating questions that evaluate low-level vs higher-level abilities.

The emphasis in the 1980s was on teaching higher-order thinking skills, and the validity of Bloom's Taxonomy was questioned. In May 1984, the Association for Supervision and Curriculum Development (ASCD) observed that students were failing on higher-level reasoning tasks. Unfortunately, the collaboration of the associations did not result in a change to Bloom's Taxonomy (Febriani, 2019).

Bloom's taxonomy was revised in 2001 by Anderson, Krathwohl, and others. The revision resulted in Bloom's latest taxonomy. The revised taxonomy introduces a two-dimensional structure to the original, which includes cognitive process and knowledge dimensions. Bloom's initial taxonomy resembles the cognitive component. Only a few significant changes have been made (C-Leslie, 2016). Another difference is that the position of cognitive levels, assessing (C5), has now taken precedence overproducing (C6). The following two points have been revised: (CLeslie, 2016)

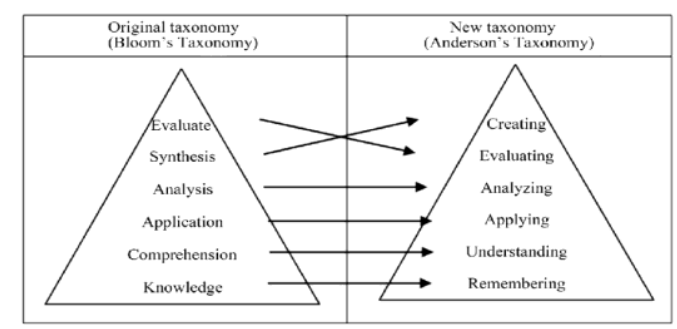


Rani Ayu Feronica, et.al: The Implementation of Higher Order Thinking Skill (HOTS) in Junior High School: Teaching Practice and Problems- 191

\section{Diagram 1. Anderson Taxonomy}

According to Anderson and Krathwohl, current education should focus on moving away from non-algorithmic instruction emphasizing low-level thinking (LOTS) and learning to prioritize high-level thinking skills (HOTS) (Syarifah, Usodo, \& Riyadi, 2019). Anderson and Krathwohl's revised Bloom's taxonomy separates the cognitive mechanism into two dimensions: First, in C1 Memorizing: Retrieving, Remembering, and Recalling Specific Information from Long-Term Memory, Low Order Thinking (LOT) is described. C2 Understanding is the process of deriving, interpreting, exemplifying, categorizing, summarizing, inferring, comparing, and explaining context from oral, textual, and visual communications. C3 carrying out or enforcing: carrying out or enforcing an action. According to C4 Analyzing, Higher Order Thinking (HOT) is the act of breaking down content into constituent pieces and identifying how the parts link to one another and an overall structure or function through differentiating, organizing, and assigning. C5 Analyzing: the process of examining and assessing information to make judgments based on criteria and standards. C6 Creating: assembling pieces to form a coherent or functional whole; rearranging elements into a new pattern or structure via development, design, or production (Syarifah et al., 2019).

To study science, students must have high-order thinking skills (HOTS). As a result, when teachers use instructional involving pedagogy to assist students in improving higher-order thought skills (HOTS), they are directly striving to improve student achievement. Thinking skills can be applied to all fields by asking students thought-provoking questions (Mohd Nazri et al., (2017).

Problems like these, on the other hand, can be overcome by using rational and creative reasoning, as well as inferring from prior experience. High-order thinking skills (HOTS) are characterized by dynamic, self-regulatory, substantive, nuanced judgments, ambiguity, multiple criteria, and multiple providing solutions. High or thinking skills (HOTS) should be an essential element of the teaching and learning process since one of the major aims of education is to guarantee that students can think critically and solve issues (Rohis, 2019)

The 2013 Curriculum's High order thinking skill (HOTS) has also highlighted the balance of skills in the students' cognitive domain and those in the students' affective domain (Jailani, Sugiman, \& Apino, 2017). In the classroom, to be able to create learning activities into active learning, as one stage of the research, researchers arrange specific guided 
discovery learning model (Laila Sulastri, Wahidin, Muchtar, \& Lestari, 2016)

In the classroom, teachers as the agents of change need to understand, practice, and apply High order thinking skills (HOTS) to teach the skills effectively. More importantly, to ensure the objective of any educational program concerning High order thinking skills (HOTS) is achieved, teachers' knowledge and beliefs are indeed the determining Abdul Aziz@ @ Ahmad et al, (2017). Investigating the problem is that High order thinking skills (HOTS) Students' ownership is still quite low. Highorder thinking skills (HOTS) focus on pupils' ability to judge a situation rather than merely memorize it. Students are expected to be able to assess problems and develop solutions to them (Kusumawati, Dwiranti, \& Salamah, 2018).

\section{RESEARCH METHODOLOGY}

To answer the study questions, Descriptive Qualitative was employed. The goal of qualitative research is to create explanations for social events as they occur in the wild. Descriptive research is a detailed examination of current events and situations by the topic. This study's participants are four English teachers. The researcher used a questionnaire and interview to find out the data about teaching practice and implementation of HOTS in SMPN 1 Rejang Lebong. The data is analyzed by using

\section{RESULTS \& DISCUSSION}

\section{Results}

\section{Teaching Practice of HOTS Implementation}

Based on the questionnaire, the researcher found that the teaching practice of HOTS implementation in SMPN 1 Rejang Lebong. The result can be seen in the following table:

Table 1.

Teaching Practice of HOTS Implementation

\begin{tabular}{|c|l|c|l|l|l|}
\hline No & \multicolumn{1}{|c|}{ HOTS } & ET 1 & ET2 & ET3 & ET4 \\
\hline 1. & Remembering & $\sqrt{ }$ & $\sqrt{ }$ & $\sqrt{ }$ & $\sqrt{ }$ \\
\hline 2. & Understanding & $\sqrt{ }$ & $\sqrt{ }$ & $\sqrt{ }$ & $\sqrt{ }$ \\
\hline 3. & Applying & $\sqrt{ }$ & $\sqrt{ }$ & $\sqrt{ }$ & $\sqrt{ }$ \\
\hline 4. & Analyzing & $\sqrt{ }$ & $\sqrt{ }$ & $\sqrt{ }$ & $\sqrt{ }$ \\
\hline 5. & Evaluating & $\sqrt{ }$ & $\sqrt{ }$ & $\sqrt{ }$ & $\sqrt{ }$ \\
\hline
\end{tabular}


Rani Ayu Feronica, et.al: The Implementation of Higher Order Thinking Skill (HOTS) in Junior High School: Teaching Practice and Problems- 193

\begin{tabular}{|l|l|l|l|l|l|}
\hline 6. & Creating & $\sqrt{ }$ & $\sqrt{ }$ & $\sqrt{ }$ & $\sqrt{ }$ \\
\hline
\end{tabular}

Based on table 1. All English Teacher in SMPN 1 Rejang Lebong uses six-level in HOTS implementation. They were remembering, understanding, applying, analyzing, evaluating, and creating. It can be concluded that HOTS implementation in SMPN 1 Rejang Lebong is well implemented in the teaching and learning process.

\section{English Teacher 1}

The teaching practice of HOTS implementation by English teacher 1 was: remembering, understanding, applying, analyzing, evaluating, and creating. In creating, the English teacher is recalling students' long-term memory about the material. This way is used to make students interested before learning while material. In understanding. English teacher shares the material using pictures, videos, songs, etc. to make students easy songs understand the materials. In applying, English teachers teach materials using teachers' techniques and strategies like a discussion group, presentation, problem-based learning, and project-based learning. In analyzing, the English teacher asks the students to analyze the topic in the course. Students can relate the materials to the environment and do investigate or survey about the information related to the materials. In evaluating, English teacher do evaluate students' materials understanding using tasks, quiz, or examination. In this component, the English teacher also makes students evaluate their problems and knowledge about the material. In creating, English teacher uses material and make students create some decision about the material.

\section{English Teacher 2}

Teaching practices of HOTS implementation by English teacher 2 were: remembering, understanding, applying, analyzing, evaluating, and creating. The first level is creating, in this level, English teachers use some pictures, videos, songs, film, graphs, etc. to recall their students' memories about the material. The second component is understanding. English teacher uses experience and pictures to make students more understand the material. Third, the level is applying, English teacher uses Youtube, Instagram, Google Classroom, WhatsApp Group to make students more interested in the learning process. The fourth component is analysis, English teacher asks students to criticize material individually and in a group. Students can discuss with their partners in the classroom and their friend in another classroom via social media. 
The fifth level is evaluating, English teachers do evaluate students' understanding of the material. English teacher makes students write their problems in this section and makes them solve their problems for the next meeting. The sixth level is creating, English teacher uses some material to make students critical thinking to create something about the topic and makes a key point of this section.

\section{English Teacher 3}

Teaching practices of HOTS implementation by English teacher 3 were: remembering, understanding, applying, analyzing, evaluating, and creating. First is creating, the English teacher is recalling student's long memory about the material. Next is understanding. English teacher uses social media for learning to make students more interested and understand the material. Then is applying, English teacher teaches materials by using discussion group and presentation. Then is analyzing, the English teacher asks students to think critically about the material. Next is evaluating. In this component, English teachers evaluate their students' problems with the material. Last is creating, English teacher some project to make students create new media or tools in learning.

\section{English Teacher 4}

Teaching practices of HOTS implementation by English teacher 4 were: remembering, understanding, applying, analyzing, evaluating, and creating. In creating, English teachers make students interested before learning while material. In understanding. English Teachers use some pictures, songs, and videos to make students easy to understand the materials. In applying, English teacher uses presentation, think-pairshare, discussion group, debate, etc. to make students critical thinking in the classroom. In analyzing, the English teacher asks students to analyze the topic in the course. In evaluating, English teachers do evaluate students' problems and knowledge about the material. In creating, the English teacher uses some material and asks students to make key-point about it. English teacher also asks students to create a new project about the material.

\section{Teaching Problems of HOTS Implementation}

The researcher also finds out teaching problems in implementing HOTS at SMPN 1 Rejang Lebong. The researcher uses voice notes via WhatApp to know English teacher problems in HOTS implementation. 
The results of the interview with the English teacher are explained in detail in the next point.

\section{English Teacher 1}

$\begin{array}{ll}\text { Researcher } & \text { What are your problems in implementing } \\ \text { English Teacher 1 } & \text { HOTS? } \\ & \text { I have problems with time and } \\ \text { knowledge about HOTS. I have limited } & \text { time in teaching English by using HOTS. } \\ & \text { As we know that, teaching English by } \\ & \text { using HOTS is need more time to prepare } \\ & \text { the material and implement the material. } \\ & \text { I am not an expert in HOTS. I am not } \\ & \text { focused in teach English by using social } \\ & \text { media, etc. }\end{array}$

\section{English Teacher 2}

Researcher

English Teacher 2
: What are your problems in implementing HOTS?

: I have limited access and connection to using the internet to implement HOTS in my home. I have a problem with the preparation of the material. I have a lot of jobs to design the material and my teacher's administration. It makes me take much time to finish this.

\section{English Teacher 3}

Researcher

English Teacher 2
: What are your problems in implementing HOTS?

: I have a problem in using ICT in the classroom to implement HOTS. I have limited training in using ICT. I have a laptop am sharing with my family. The internet connection is not good in my house. I do not have friends to teach me using ICT. I waste much time learning about new ICT platforms.

\section{English Teacher 4}


Researcher

English Teacher 2
: What are your problems in implementing HOTS?

: $\quad$ My problems are lack of facilities, lack of connection, lack of knowledge, and lack of motivation. I have a laptop with sharing with other families. I have no internet connection by using Wi-Fi Indi-home. I have limited knowledge about new literacies related to HOTS. I am not focused on using ICT to implement HOTS.

\section{Discussion}

Based on the findings, there are two points is discussed in this section. The first is about the teaching practice of HOTS implementation in SMPN 1 Rejang Lebong. The second is teaching problems in HOTS implementation in SMPN 1 Rejang Lebong.

Teaching practice using HOTS in SMPN 1 Rejang Lebong is the same as Anderson Taxonomy (Anderson and Krathwol, 2001). These six levels of Anderson Taxonomy: remembering, understanding, applying, analyzing, evaluating, and creating. This same finding is the same as Rosi (2019). Rois's finding said that six-level students are learning in HOTS. Wilson (2016) also explains in detail about six-level in Anderson taxonomy. English teachers use pictures, graphs, videos, movies, songs to teach English using HOTS. this finding is the same as Balakrishnan and Mohammad, 2020). Their findings said that using graphic organizers as a brainstorming method in teaching. English teachers have also used some methods to make students more interested in the classroom. Thamrin and Agustin (2019) argue that various methods in the classroom are better for students.

Teaching problems using HOTS is founded in SMPN 1 Rejang Lebong. Lack of facilities, lack of time, lack of training, lack of knowledge, lack of connection, and lack of motivation as problems in implementing HOTS in SMPN 1 Rejang Lebong. Fakhomah and Utami (2019) argue that teachers feel difficulties in teaching HOTS. This same finding by Ginting and Kuswandono (2020), Zahrani \& Elyas (2017), Tyas, et.al (2019), Retnawati (2018), and Ballakhrisnan \& Mohamad. Ginting and Kuswandono (2020) found that three problems in implementing HOTS were teacher limited knowledge and teacher preparation. Zahrani \& Elyas (2017) argues that teacher had problems in the preparation of teaching using HOTS. Tyas, et.al (2019) explain that limited material is 
Rani Ayu Feronica, et.al: The Implementation of Higher Order Thinking Skill (HOTS) in Junior High School: Teaching Practice and Problems- 197

one of the challenges teaching English by using HOTS. Retnawati (2018) argues that teachers had low knowledge of the function of HOTS. Ballakhrisnan \& Mohamad (2020) states that limited time is the problem in HOTS classrooms.

\section{CONCLUSION}

Based on the results and discussion above, the researcher makes some conclusions. First, teaching practice of HOTS implementation. The implementation of HOTS in SMPN1 Rejang Lebong were: (1) the implementation of HOTS in SMPN 1 Rejang Lebong is suitable with Anderson Taxonomy. English teachers do six-level in teaching English: remembering, understanding, applying, analyzing, evaluating, and creating. Second, teaching problems in HOTS implementation. Teaching problems of HOTS implementation in SMPN 1 Rejang Lebong were (2) Teaching problems in implementing HOTS were lack of facilities, lack of time, lack of training, lack of knowledge, lack of connection, and lack of motivation. This conclusion is hoped can be used as the reference for the government to improve our education quality especially English course.

\section{REFERENCES}

Abdul Aziz @Ahmad, A., Ismail, F., Ibrahim, N. M., \& Samat, N. A. (2017). Investigating the Implementation of Higher Order Thinking Skills in Malaysian Classrooms: Insights from L2 Teaching Practices. Sains Humanika, 9(4-2), 65-73. https://doi.org/10.11113/sh.v9n42.1361

Akbari, Z. (2015). Current challenges in teaching / learning English for EFL learners: The case of junior high school and high school. Procedia - Social and Behavioral Sciences, 199, 394-401. https://doi.org/10.1016/j.sbspro.2015.07.524

ANALYSIS OF READING COMPREHENSION QUESTIONS BY USING REVISED BLOOM 'S TAXONOMY ON HIGHER ORDER. (n.d.). 1-15.

Apriani, E. (2017). Utilizing Preservice English Teachers Strategies and Classroom Management at Junior High School in Rejang Lebong Regency. ENGLISH FRANCA: Academic Journal of English Language and Education, 1(2), 149-194.

Apriani, E., Anshori, S., \& Edy, S. (2019). Eksistensi English Zone Sebagai Media Penerapan Kemampuan Berbahasa Inggris Mahasiswa 
Program Studi Tadris Bahasa Inggris IAIN CURUP. Cendekia: Jurnal Kependidikan Dan Kemasyarakatan, 17(2), 317-332.

Apriani, E., Azizah, U. A., Morgana, R., \& Syafryadin, S. (2021). Multimodal Resources to Enrich Meaning Construction by EFL Teacher. Journal of English Education and Teaching, 5(1), 123-137.

Fairiziana, M., Rosli, M., \& Maarof, N. (2017). the Effects of Higher Order Thinking Skills (Hots) Questions in Improving Esl Pupils' Writing Performance. 2017(March), 70-80.

Jailani, J., Sugiman, S., \& Apino, E. (2017). Implementing problem-based learning in order to improve the students' HOTS and characters. Jurnal Riset Pendidikan Matematika, 4(2), 247. https://doi.org/10.21831/jrpm.v4i2.17674

Kusumawati, S. A., Dwiranti, A., \& Salamah, A. (2018). Proceeding of Biology Education. Proceeding of Biology Education, 2(1), 42-49.

Laila Sulastri, Y., Wahidin, D., Muchtar, H. S., \& Lestari, Z. W. (2016). the Implementation of Active Learning Models To Increase Pre-Service Teachers' High Order Thinking Skills. PEOPLE: International Journal of Social Sciences, 2(1), 523-532. https://doi.org/10.20319/pijss.2016.s21.523532

Nazri, M., Ramlee, Azmah, N., Yusuff, N., \& Rosnidar. (2017). Development of Higher Order Thinking Skills Module in Science Primary School: Needs Analysis. International Journal of Academic Research in Business and Social Sciences, 7(2), 624-628. https://doi.org/10.6007/IJARBSS/v7-i2/2670

Pratiwi, N. P. W., Dewi, N. L. P. E. S., \& Paramartha, A. A. G. Y. (2019). The Reflection of HOTS in EFL Teachers 'Summative Assessment. 3(3), 127-133.

Ramos, J. L. S., Dolipas, B. B., \& Villamor, B. B. (2013). Higher Order Thinking Skills and Academic Performance in Physics of College Students : A Regression Analysis. International Journal of Innovative Interdisciplinary Research, (4), 48-60. https://doi.org/ISSN 18399053

Rohmah, Z. (n.d.). TEACHING ENGLISH AS A FOREIGN LANGUAGE. 0-92.

Supriyanti, N., Triastuti, A., \& Bahasa, F. (2008). Teaching English as Foreign. 0-49. 
Rani Ayu Feronica, et.al: The Implementation of Higher Order Thinking Skill (HOTS) in Junior High School: Teaching Practice and Problems- 199

Susilo, S., Suhatmady, B., Sunggingwati, D., Farisa, H., \& Ilmi, S. (2017). The Effect of L2 Exposure Environment on Nnests' Teaching Skills and Beliefs about EFL Learning Beyond the Class. Arab World English Journal. https://doi.org/10.24093/awej/vol8no3.18

Syarifah, T., Usodo, B., \& Riyadi. (2019). Student's critical thinking ability with higher order thinking skills (HOTS) question based on selfefficacy. Journal of Physics: Conference Series, 1265, 012013. https://doi.org/10.1088/1742-6596/1265/1/012013 
200 | ENGLISH FRANCA, Vol. 5, No. 2, 2021 